\title{
AGRICULTURE IN THE UNIVERSITY COLLEGE OF THE GOLD COAST
}

\author{
By PROF. JOHN PHILLIPS
}

$\mathrm{T}$ HE Cocoa Marketing Board of the Gold Coast, with the approval of the Government, has made available to the University College of the Gold Coast the sum of $£ 1$ million for the purpose of establishing and endowing an Agricultural Research Station in the Forest Region. Of this amount, the sum of $£ 750,000$ has been allocated for investmont for staffing and other recurrent expenditure likely to be associated with the proposed Station, while the sum of $£ 250,000$ is to be available over the course of the next four years for purposes of capital development.

At a ceremony at the Agricultural Research Station of the Department of Agriculture of the College, at Nungua, near Accra, a cheque for $£ 750,000$ and one for $£ 40,000$ as the first contribution toward capital needs were presented by the chairman of the Cocoa Marketing Board to the Prineipal of the University College on February 28.

Briefly, the objectives of the proposed centre, which is to be established in an area of forest on soils considered to be typical of a large area of the forest region, include : (1) Provision of educational facilities for students of agriculture-undergraduate and senior. (2) The investigation of problems in the management of forest soil, including the possibilities of improving on existing practices in 'shifting cultivation' or 'bush fallowing' and the enhanced production of food and commodity crops both annual and perennial. (Among the commodity crops would be cocoa, coffee, cola, citrus, banana, pineappleand by some special arrangement relating to site, aspects of oil palm production.) (3) Through studies both at and beyond the centre, the gathering of information relating to the economics of production of selected commodity and other crops, with emphasis on cocoa. (4) Study of problems of production, within the forest region, of poultry, pigs and sheep in certain circumstances. (5) Application of special techniques in the removal of woody growth and the cultivation of forest soil-bearing in mind the dangers of extensive and prolonged exposure of these soils to insolation and heavy and consistent rainfall. (6) The organization of a centre on which professional advisory service of a non-routine nature relating to forest agriculture could be based. (7) Establishment of a centre at which scientific and other research workers concerned in the problems of forest agriculture could work, on invitation, from time to time.

The proposed Station is a logical successor to the first research centre established by the University College in 1952 at Nungua, on the Accra Plains, for students of agriculture and for research into the classification and development of soils ; crop production under irrigation and on rain-fed land; animal production and pasture management; aspects of soil and water conservation; mechanization of agriculture and agricultural management and economy. The progress at this Station has been sufficiently encouraging to attract the interest of the authorities to an extension of the University College's activities to the most important economic region in the country, that of the mixed evergreen forests.

The University College is in special relationship with the University of London in respect of academic standards, examinations and the conferment of degrees. At the present there are eleven men reading agriculture in the first, three in the second and three in the final year of the agricultural course proper. Special scholarships for men reading agriculture at the College are offered by the Cocoa Marketing Board and the Agricultural Development Corporation of the Gold Coast. A wide range of research by members of the staff is in progress.

\section{THE ART OF SCIENCE}

DROF. L. C. BEADLE'S inaugural address, "The Art of Science", which he delivered on October 28, 1954, at Makerere University College of East Africa, Kampala, Uganda, on taking up the chair of biology there, and which has now been published*, is a brilliant exposition of the thesis that every educated person should know something of the history of science and of the nature of creative research. No summary can do justice to an address which abounds in humour, in sense and frank avowals of the author's convictions, but which can scarcely be quoted without distorting the balance of his argument. $\mathrm{He}$ starts by insisting that the inclusion of a subject in the curriculum of a university cannot be justified solely on grounds of utility and that no one can fully understand the nature of science without some knowledge of its history. He pauses in his survey of the history of science to observe that the medieval conception of science as a finite body of

* The Art of Science : an Inaugural Address delivered at Makerere University College of East Africa, Kampala, Uganda, on October 28th, 1954. By Prof. L. C. Beadle. Pp.iii +32 . (London : Oxford University Press, 1955.) 3s. 6d. net. established facts is exactly what science is not, and to comment that so far there has been a sufficient number of practising scientists in the teaching profession to frustrate the attempts made during the present century to revive the conception through the invention of examinations. Turning to the biological sciences, he points out that the main creative act in biological research is the decision as to what the problem is, and then the posing of the right questions; he does not believe that the biologists can entirely avoid considering the problem of mind and body. If, however, the great progress now being made, with the aid of new techniques, in the physiology of brain and nervous system, on one hand, and in the study of animal behaviour, on the other, leads to the two streams meeting at any point, there should be results of great practical value, and the combined streams might be deep enough for the psychologists and philosophers to navigate.

In dealing finally with the question, "What is the art of science ?", Prof. Beadle remarks that the first and greatest exponents of the scientific method, 